\title{
Ken uzelve
}

Citation for published version (APA):

Joordens, J. C. A. (2019). Ken uzelve: wat we kunnen leren van menselijke evolutie. Maastricht University. https://doi.org/10.26481/spe.20190613jj

\section{Document status and date:}

Published: 13/06/2019

DOI:

10.26481/spe.20190613jj

Document Version:

Publisher's PDF, also known as Version of record

\section{Please check the document version of this publication:}

- A submitted manuscript is the version of the article upon submission and before peer-review. There can be important differences between the submitted version and the official published version of record.

People interested in the research are advised to contact the author for the final version of the publication, or visit the DOI to the publisher's website.

- The final author version and the galley proof are versions of the publication after peer review.

- The final published version features the final layout of the paper including the volume, issue and page numbers.

Link to publication

\footnotetext{
General rights rights.

- You may freely distribute the URL identifying the publication in the public portal. please follow below link for the End User Agreement:

www.umlib.nl/taverne-license

Take down policy

If you believe that this document breaches copyright please contact us at:

repository@maastrichtuniversity.nl

providing details and we will investigate your claim.
}

Copyright and moral rights for the publications made accessible in the public portal are retained by the authors and/or other copyright owners and it is a condition of accessing publications that users recognise and abide by the legal requirements associated with these

- Users may download and print one copy of any publication from the public portal for the purpose of private study or research.

- You may not further distribute the material or use it for any profit-making activity or commercial gain

If the publication is distributed under the terms of Article $25 \mathrm{fa}$ of the Dutch Copyright Act, indicated by the "Taverne" license above, 
Prof. Dr. José Joordens

\section{Ken Uzelve}

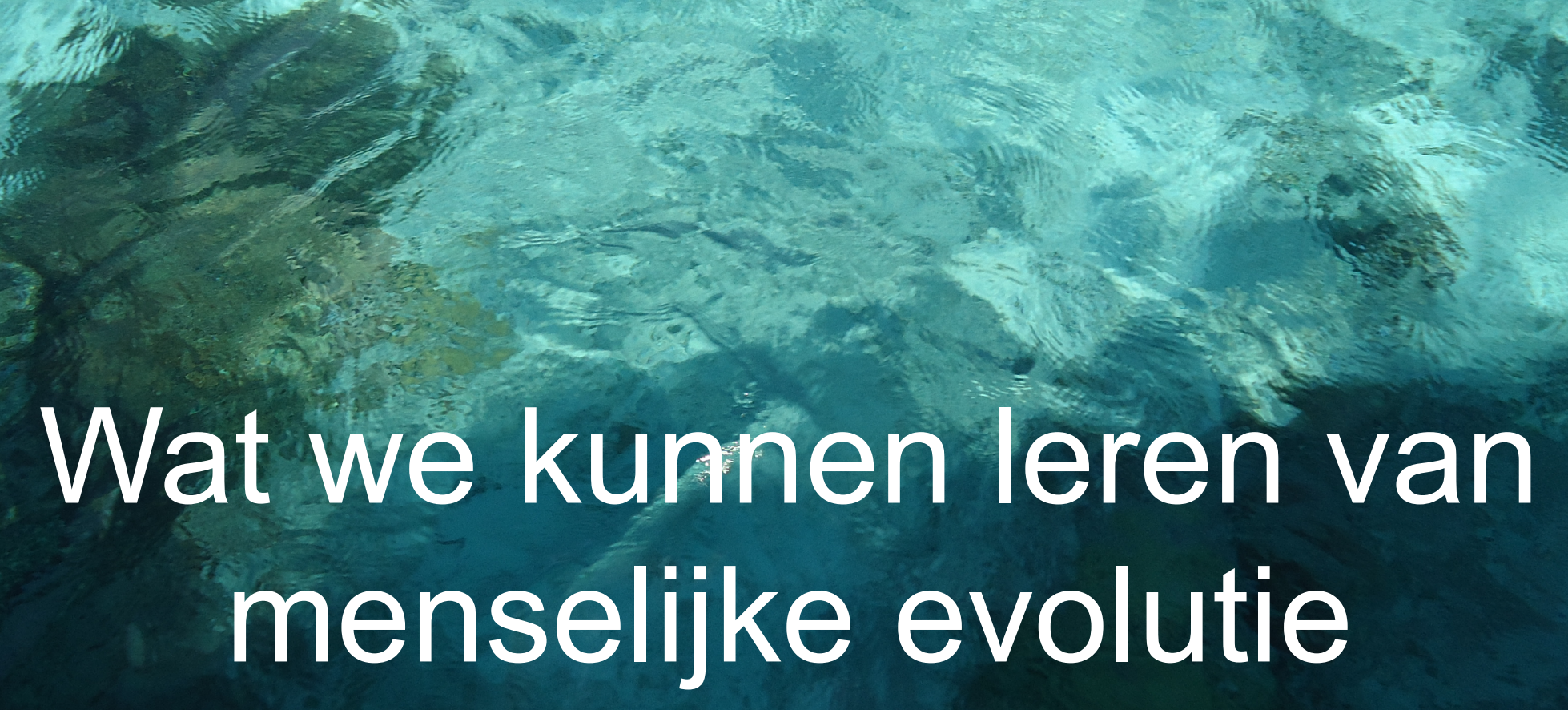




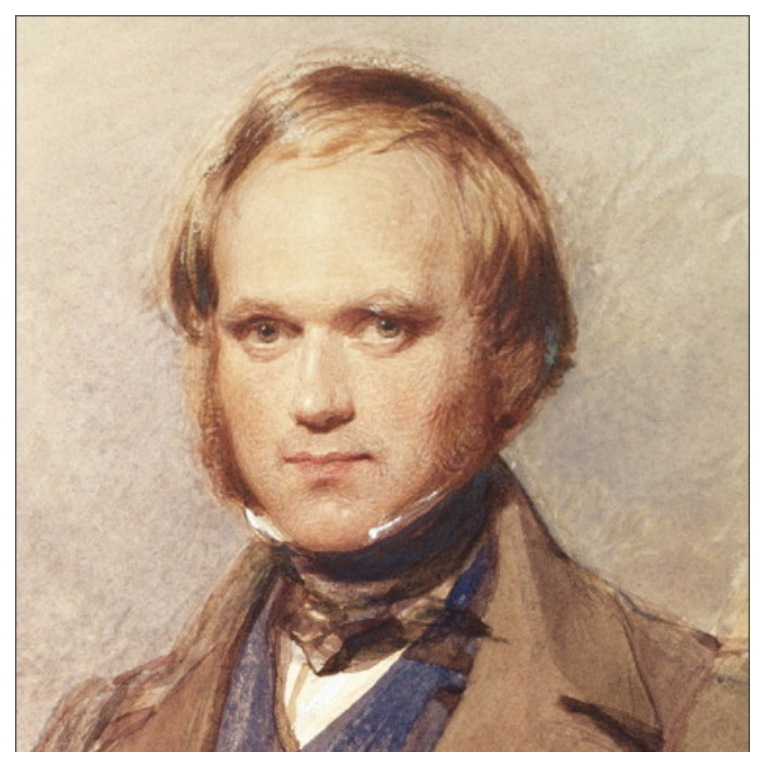

ON

THE ORIGIN OF SPECIES

BY MEANS OF NATURAL SELECTION,

OR THE

PRESERVATION OF FAVOURED RACES IN THE STRUGGLE FOR LIFE.
THE

\section{DESCENT OF M A N,}

AND

SELEGTION IN RELATION TO SEX. 
HAECKEL'S EVOLUTION OT MAN.

\section{PEDIGREE OF MAN.}
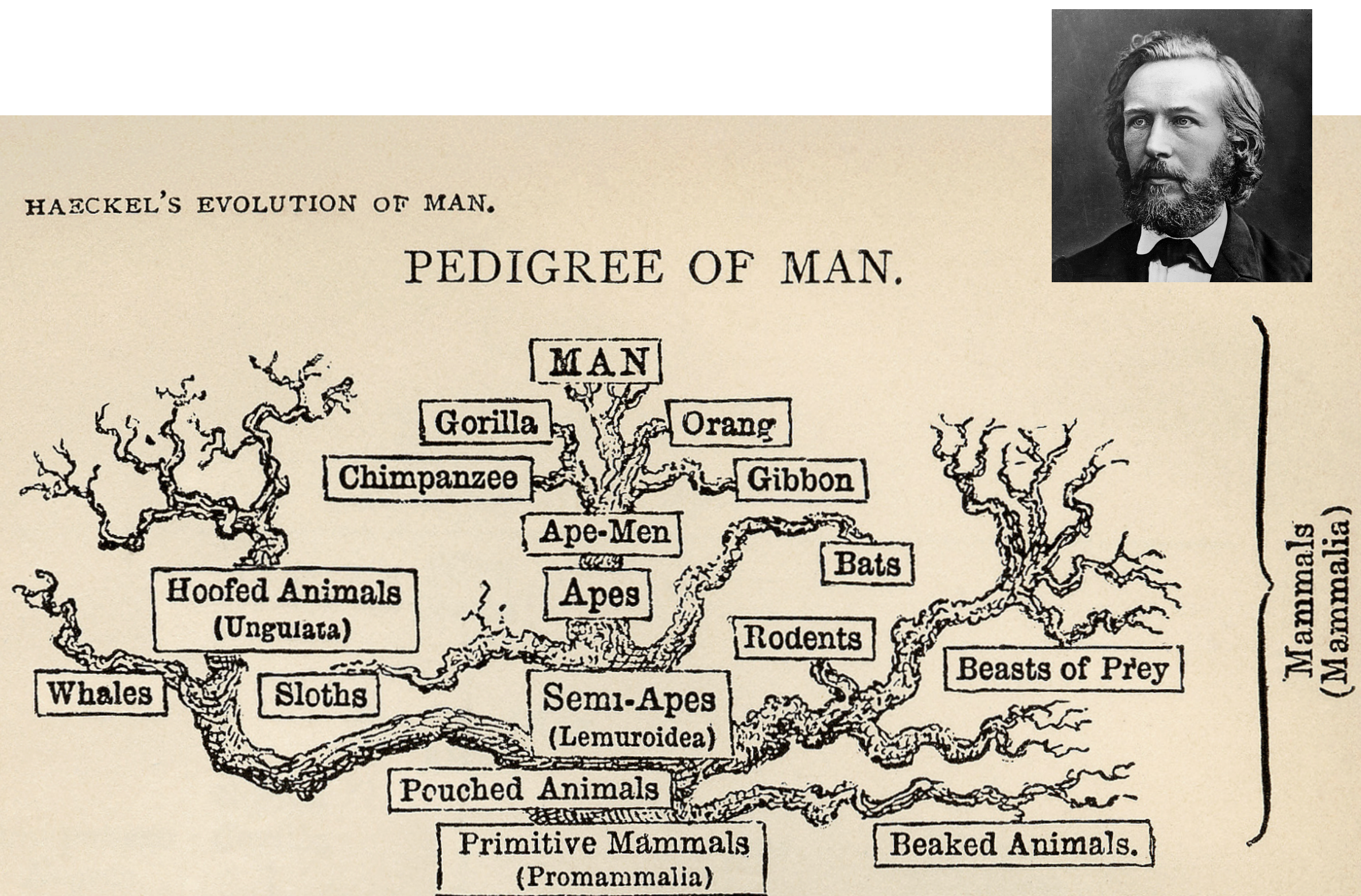

Haeckel, 1879 


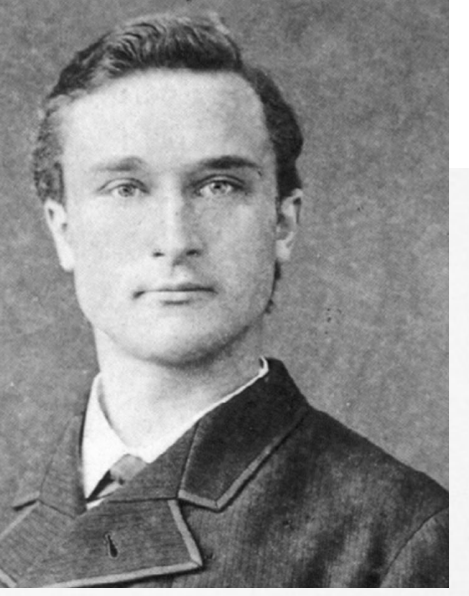

$$
\text { Ja. }
$$

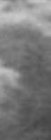

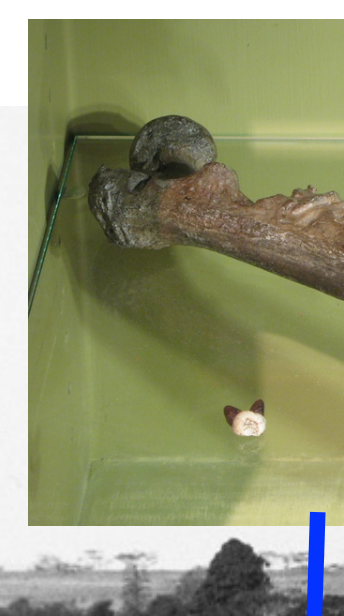

\section{PITHECAVTIRIOPIS RRECTIS.}

E IN E

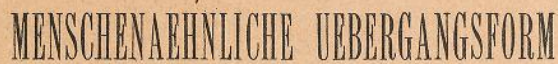

A US

J A V A.

VON

EUG. DUBOIS,

Trinil, 1894 


\section{Ouderdom mensachtige soorten}

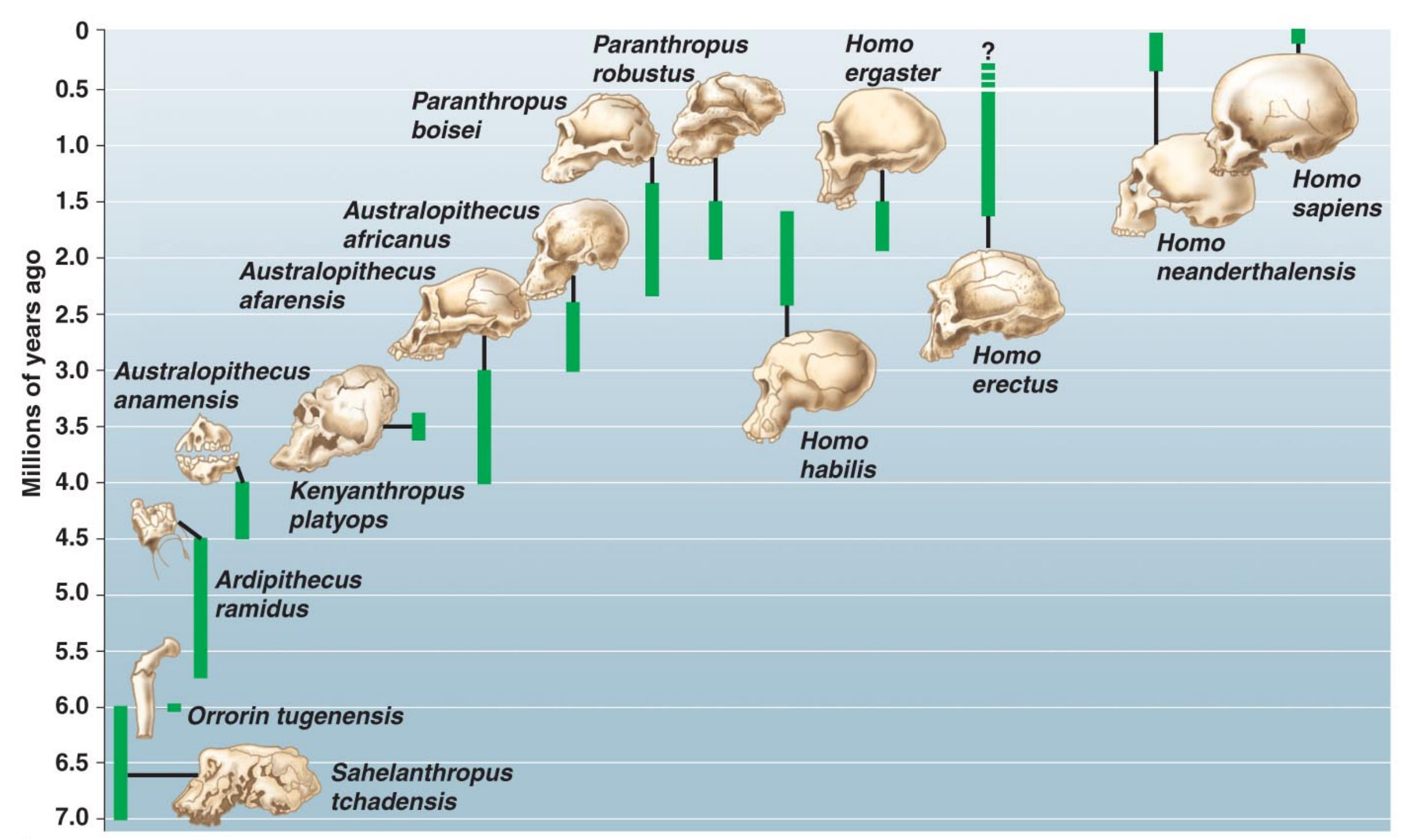


Chimpansee

\section{Mens}
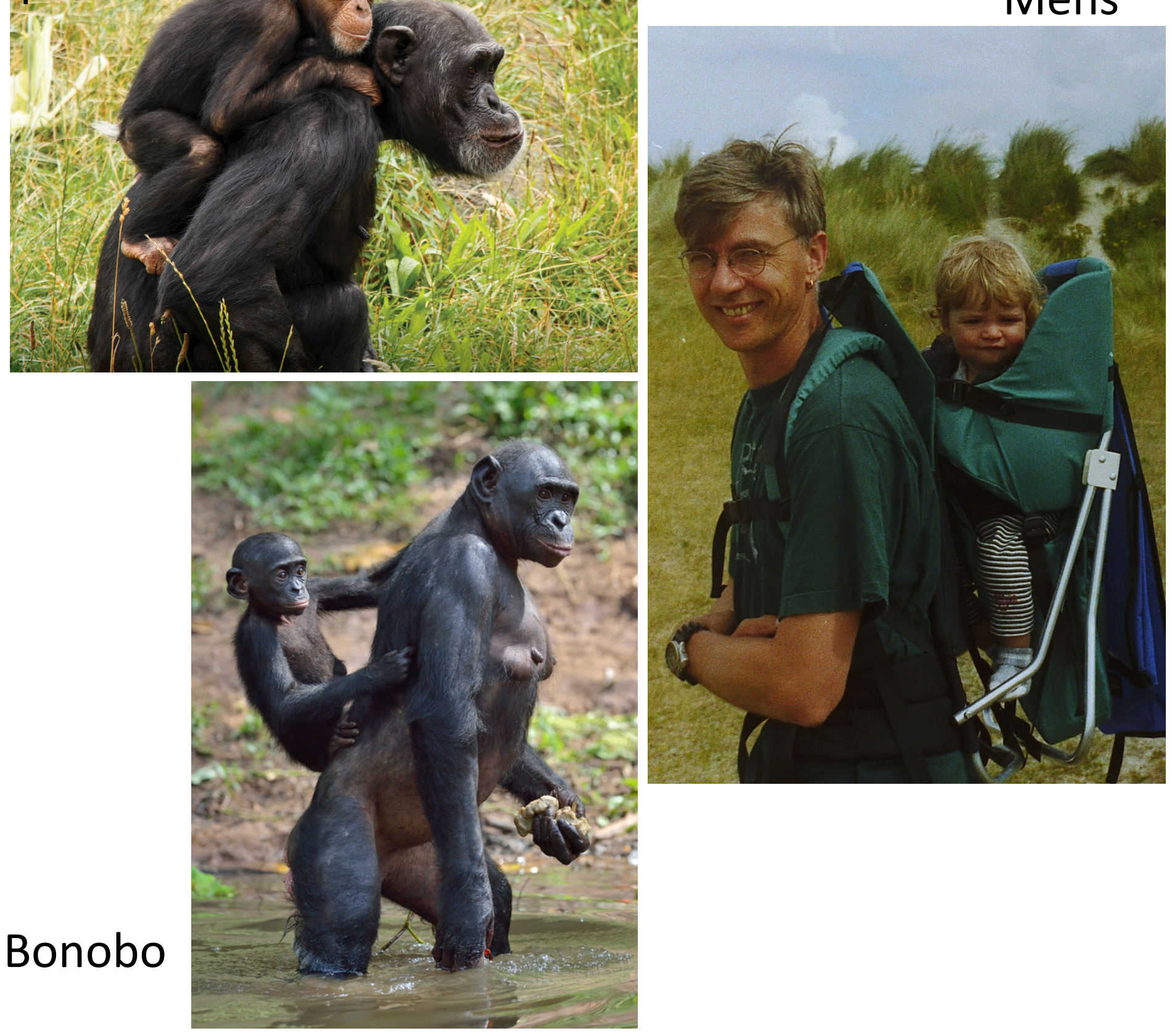


$$
\operatorname{sectit}
$$




\section{Snijsporen op 2 miljoen jaar oude waterdieren}

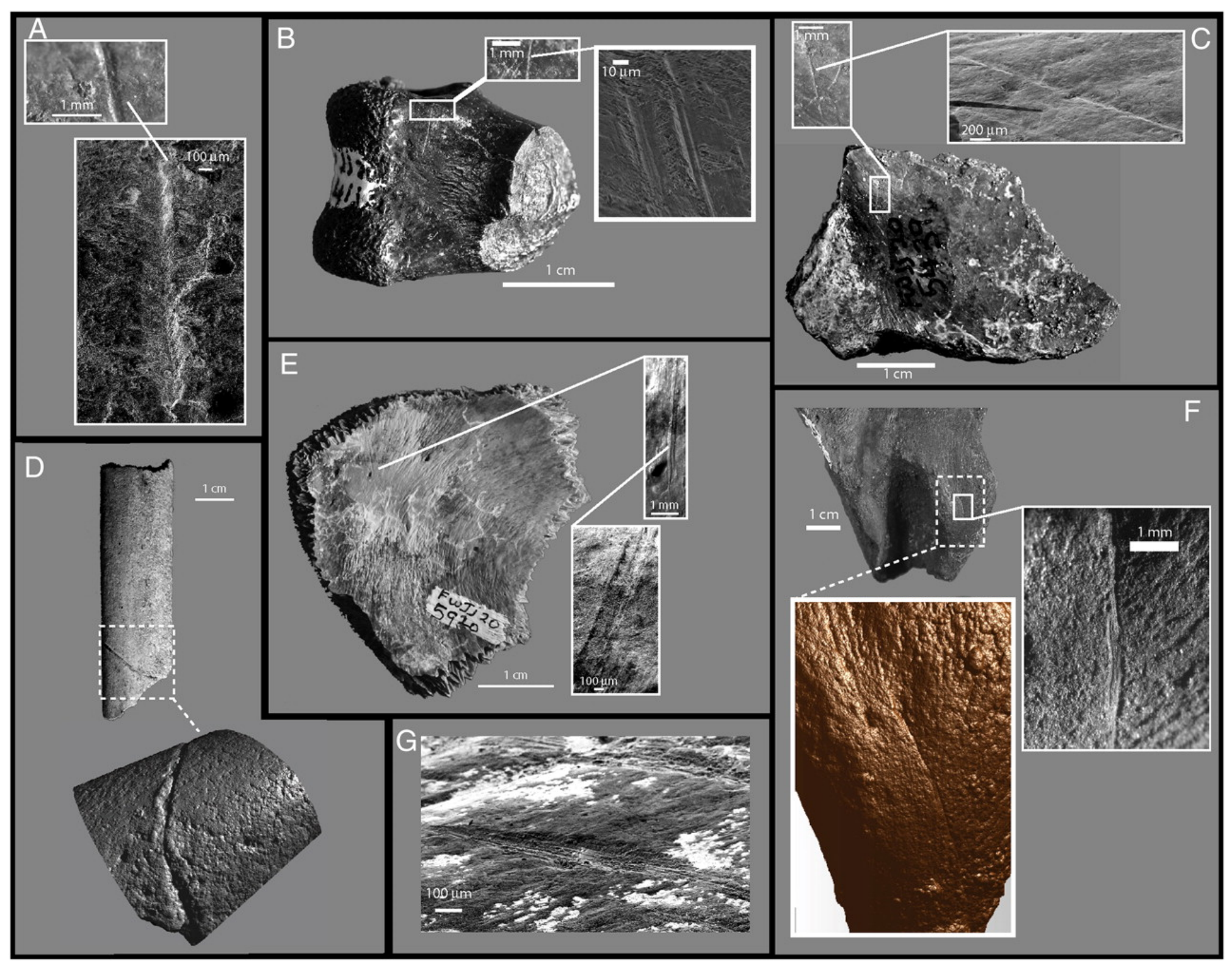

Braun et al., 2010 



\section{$0^{\top} \mathrm{d}$ wang en 우 verzet}
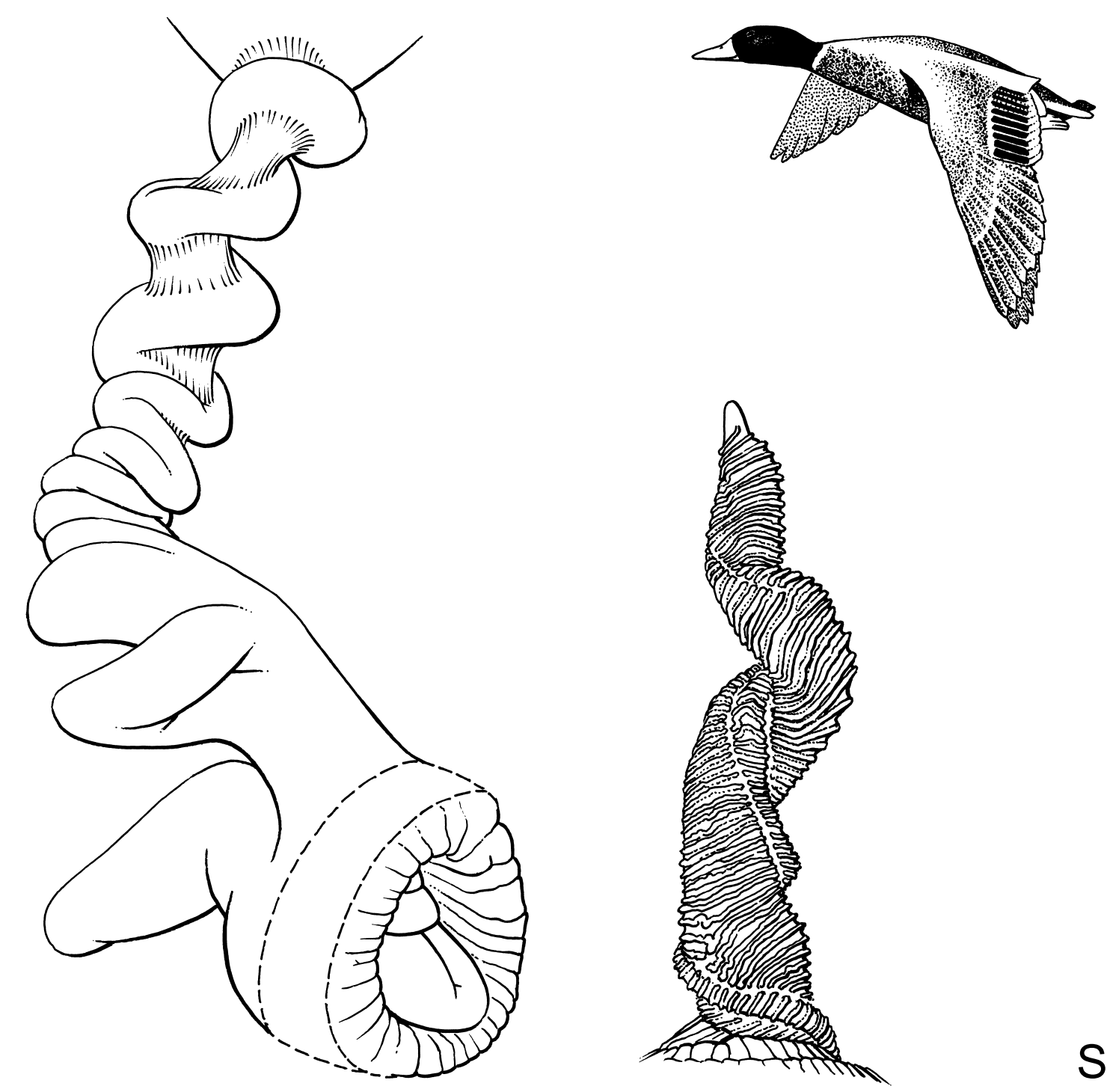

Schilthuizen, 2014 

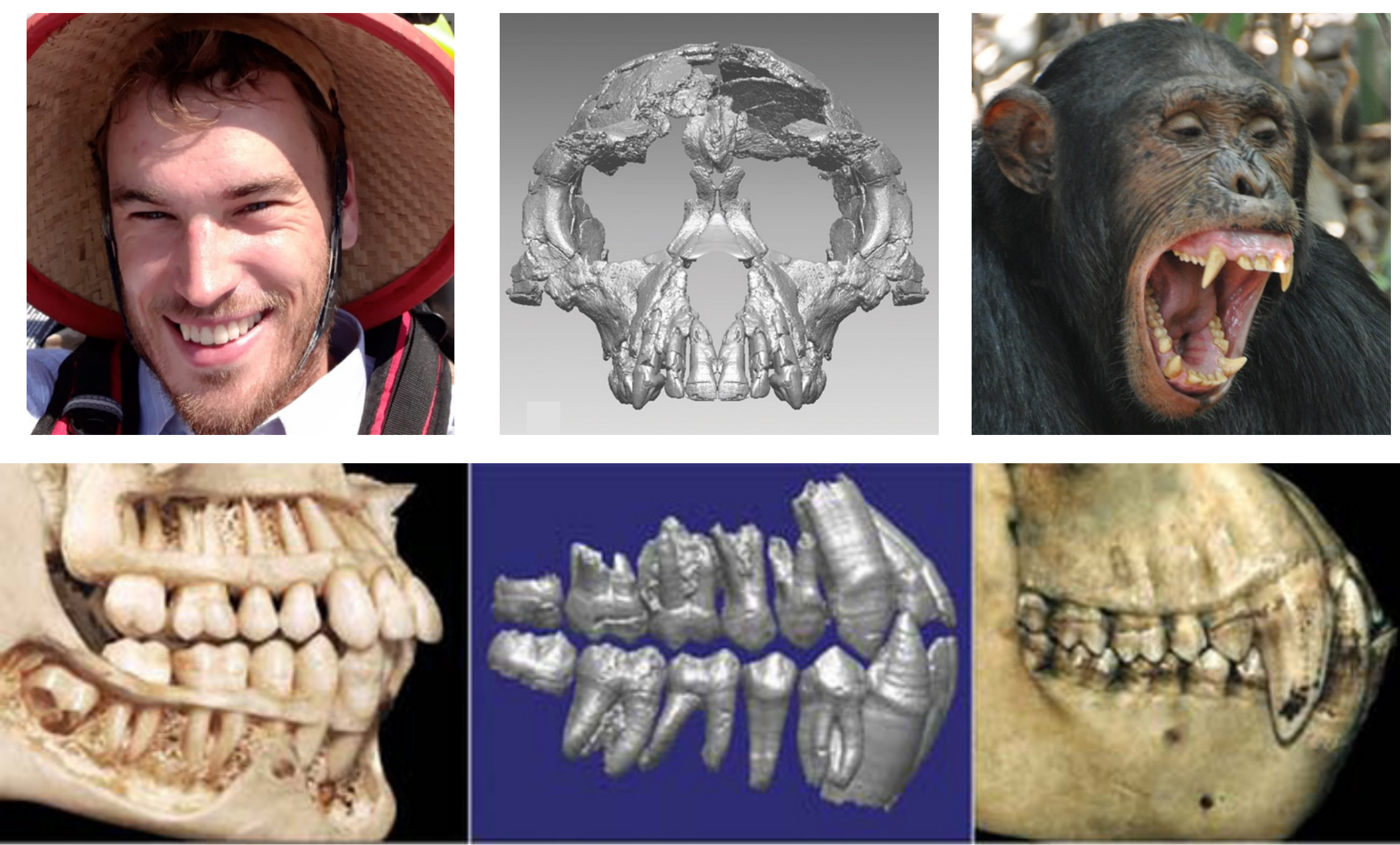

Mens

Ardipithecus ramidus 4.4 Mj oud

Chimpansee

Figuur: White, 2009 

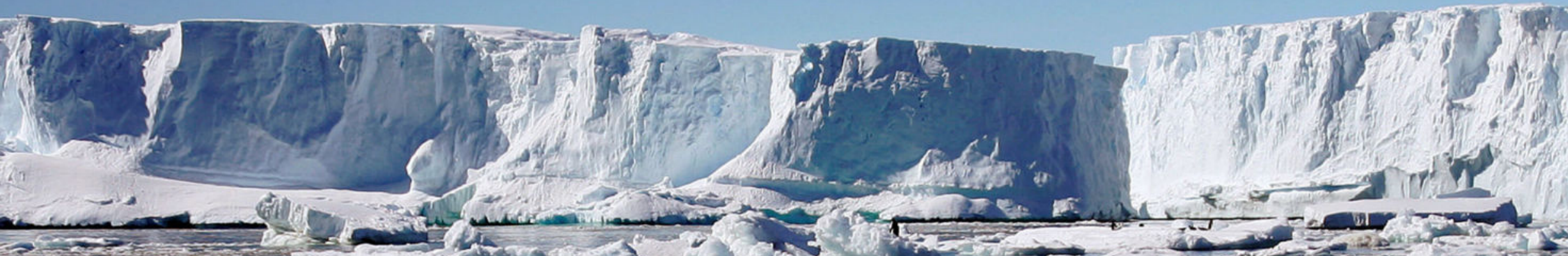
P.

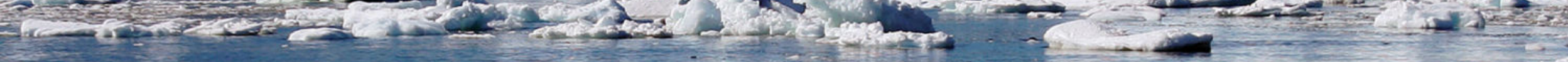

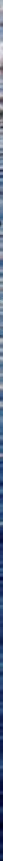




\section{Klimaat werd droger en kouder vanaf 7 en $3 \mathrm{Mjg}$}

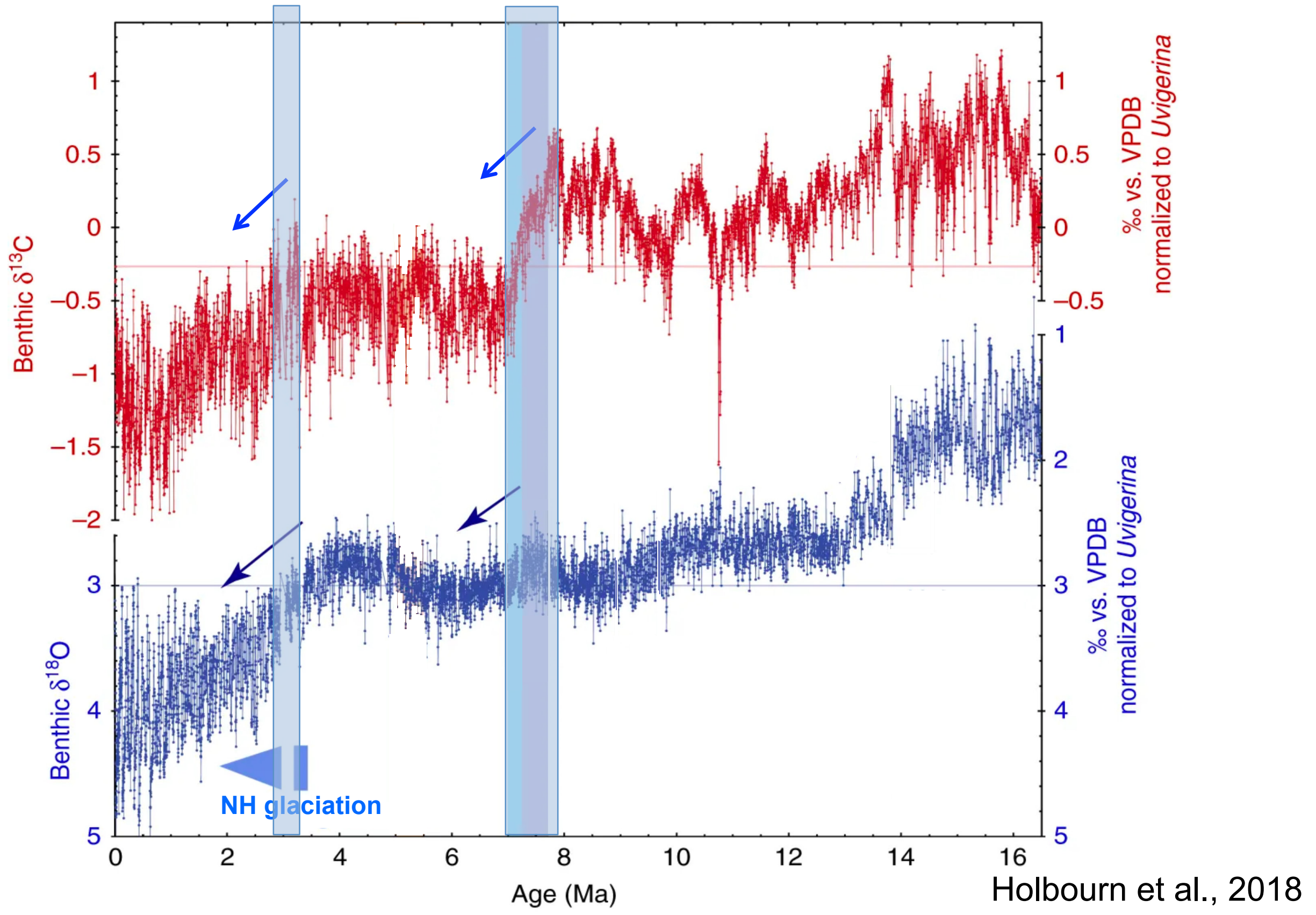




\section{Mensachtigen van alle tijden}

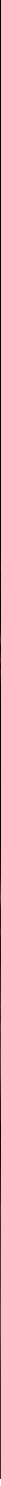

Reconstructies door Élisabeth Daynès 
Noordzee, 1994

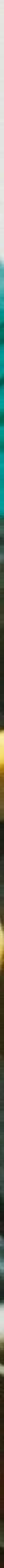




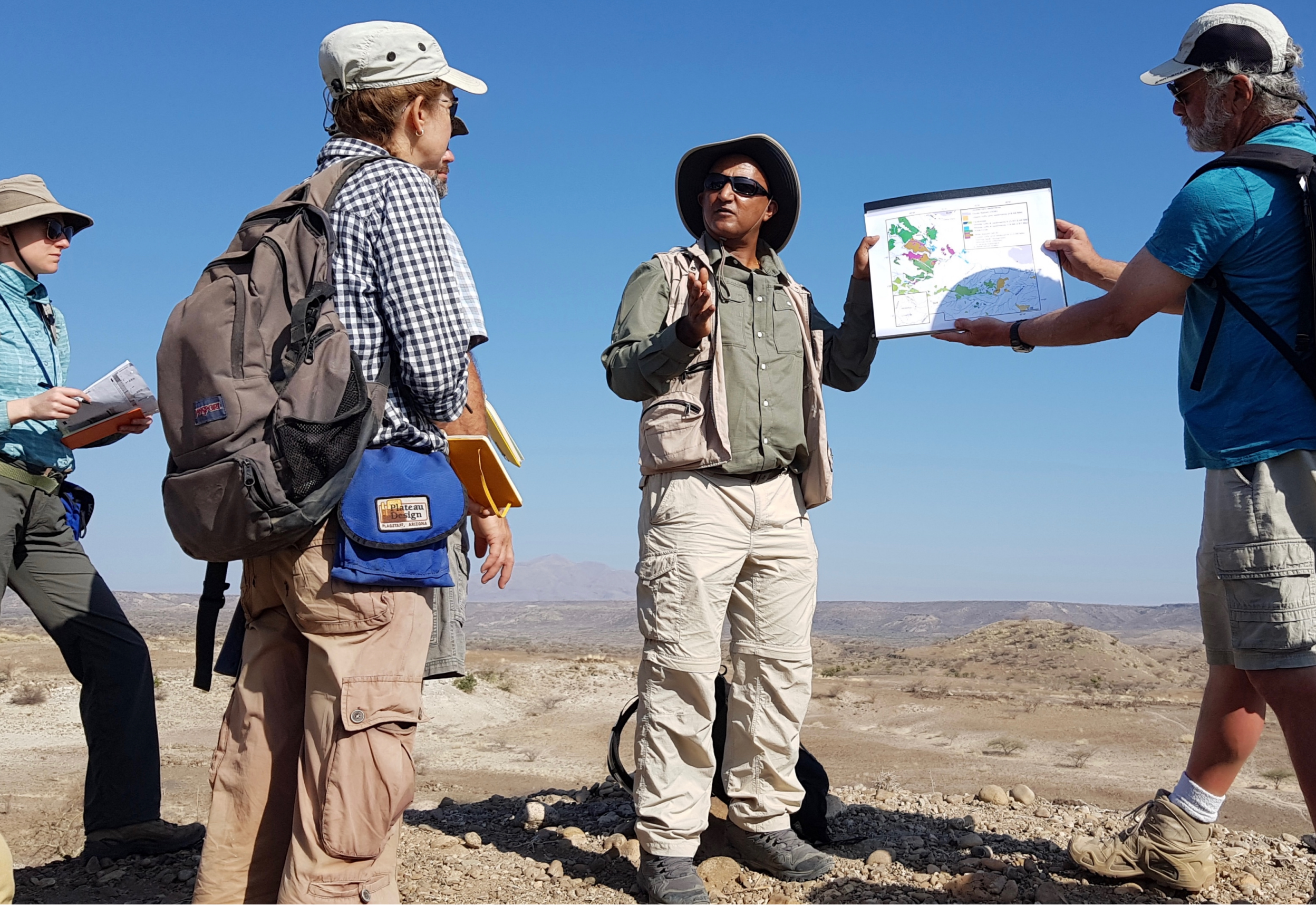

Afar in Ethiopië, 2019 
Hypothetische stamboom van 48 soorten
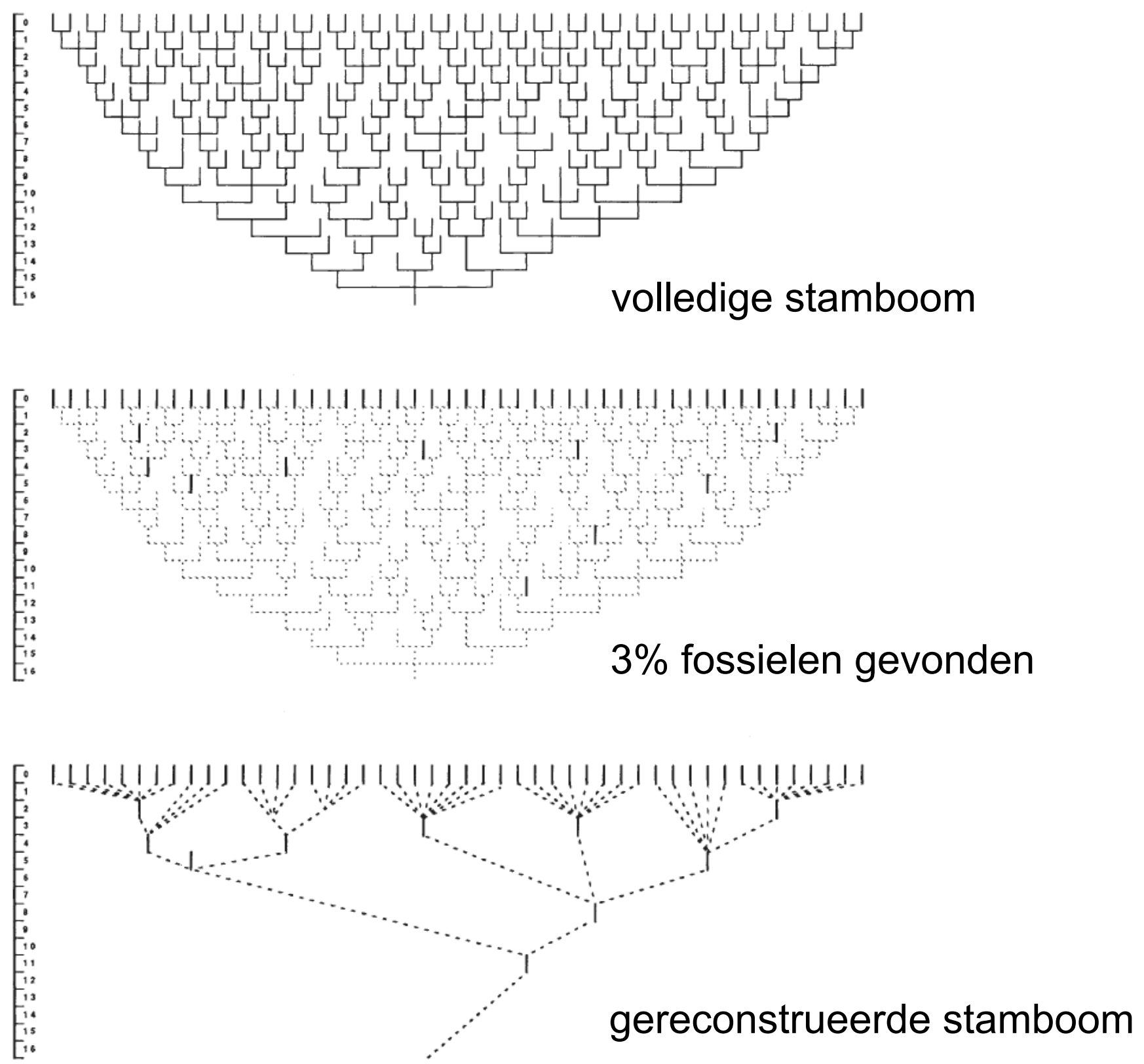

Martin, 1993 


\section{Overzicht mensachtige soorten}

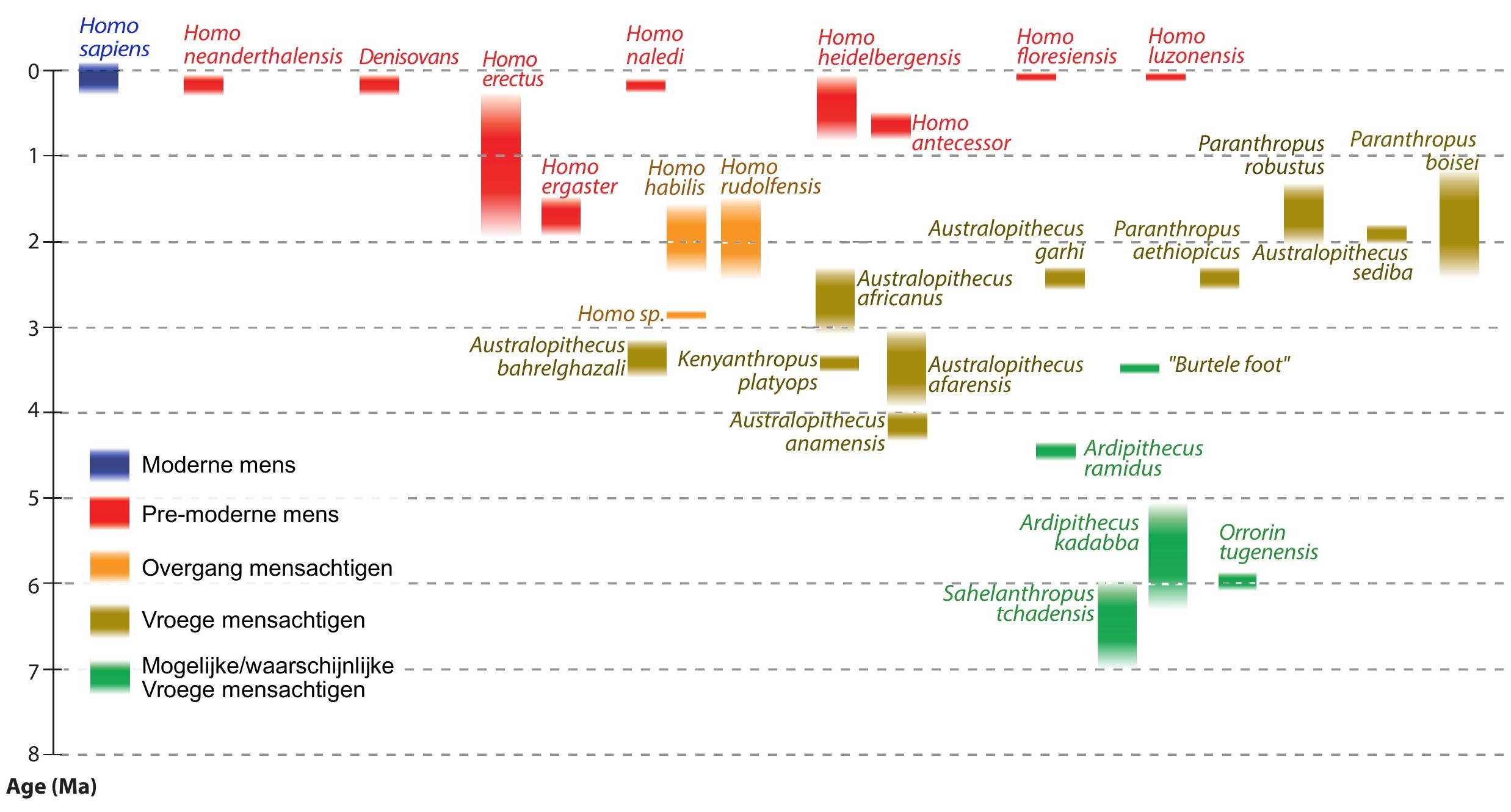

Aangepast op basis van Levin, 2015 


\section{DNA analyse: seksuele vermenging tussen soorten}

\section{Denisovans}

Modern humans

Neanderthals

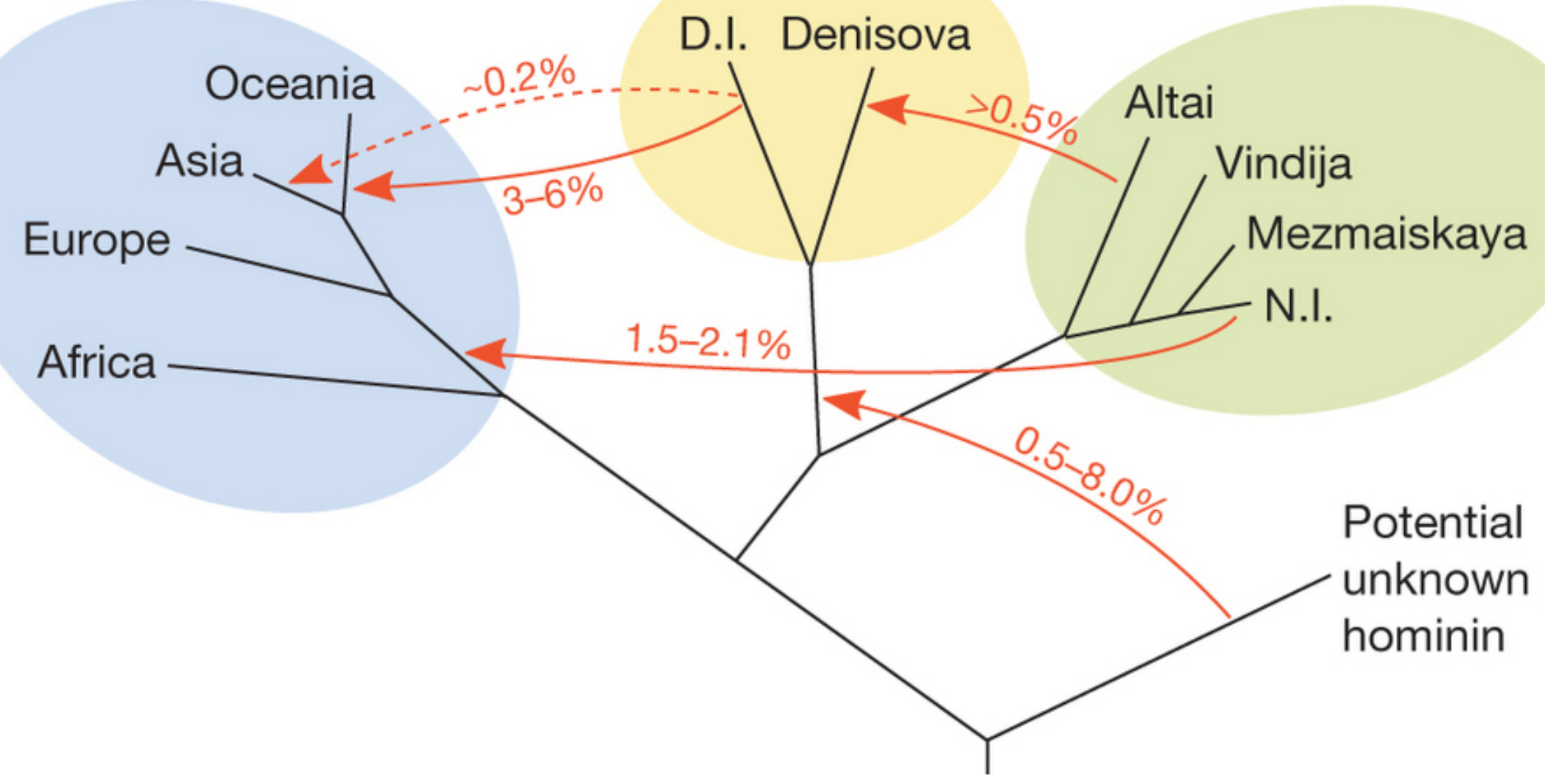

Dannemann \& Racimo, 2018 


\section{Hominin Paleocology and Evolution}

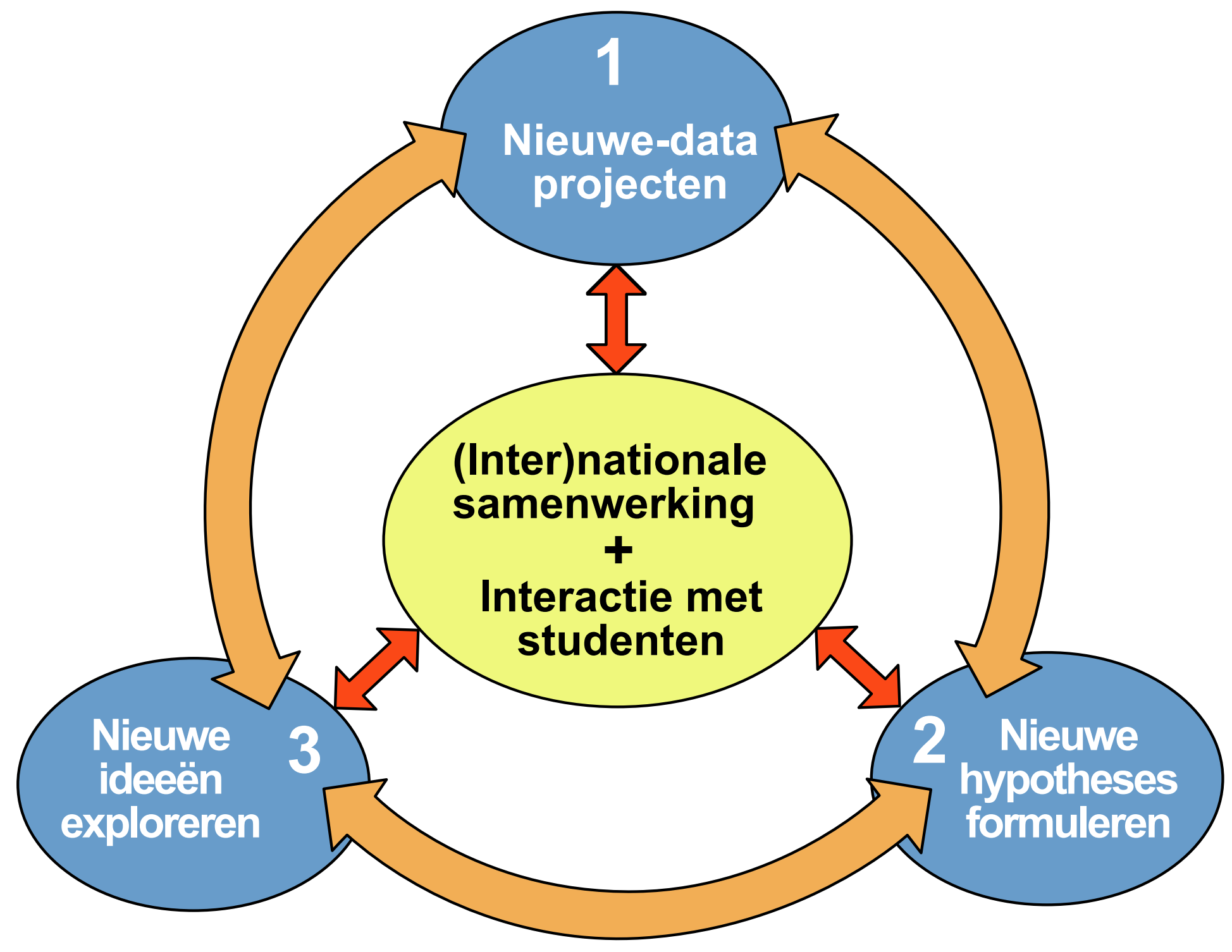




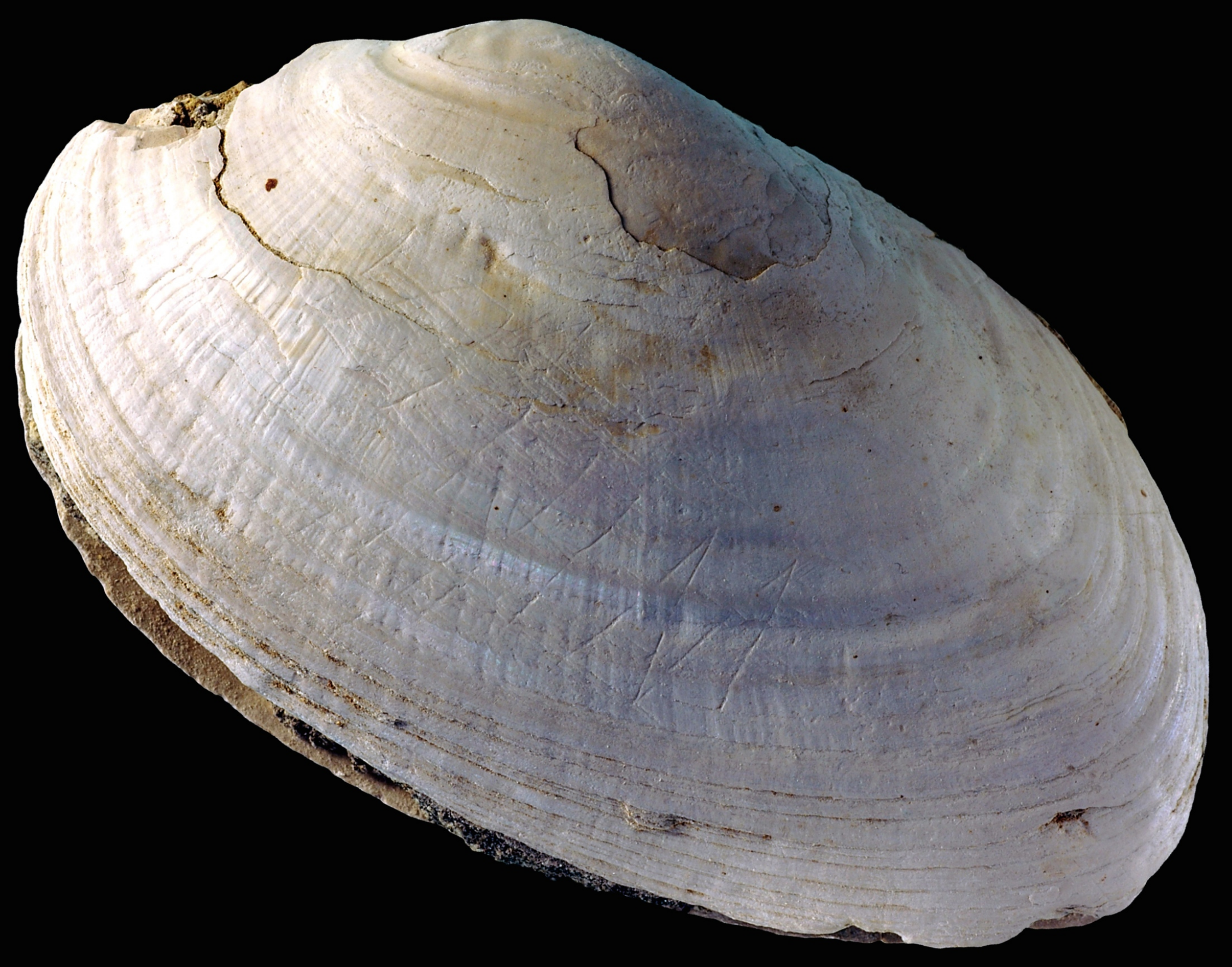




\section{LETTER}

\section{Homo erectus at Trinil on Java used shells for tool production and engraving}

Josephine C. A. Joordens $s^{1,2}$, Francesco d'Errico ${ }^{3,4}$, Frank P. Wesselingh ${ }^{5}$, Stephen Munro ${ }^{6,7}$, John de $\operatorname{Vos}^{5}$, Jakob Wallinga ${ }^{8,9}$ Christina Ankjærgaard ${ }^{8,9}$, Tony Reimann ${ }^{8,9}$, Jan R. Wijbrans ${ }^{2}$, Klaudia F. Kuiper ${ }^{2}$, Herman J. Mücher ${ }^{1,10}$, Hélène Coqueugniot $^{3}$, Vincent Prié ${ }^{11,12}$, Ineke Joosten ${ }^{13}$, Bertil van Os $^{13}$, Anne S. Schulp ${ }^{2,5,14}$, Michel Panuel ${ }^{15,16}$, Victoria van der Haas ${ }^{1}$,

Wim Lustenhouwer ${ }^{2}$ John J. G. Reijmer ${ }^{2} \&$ Wil Roebroeks ${ }^{1}$

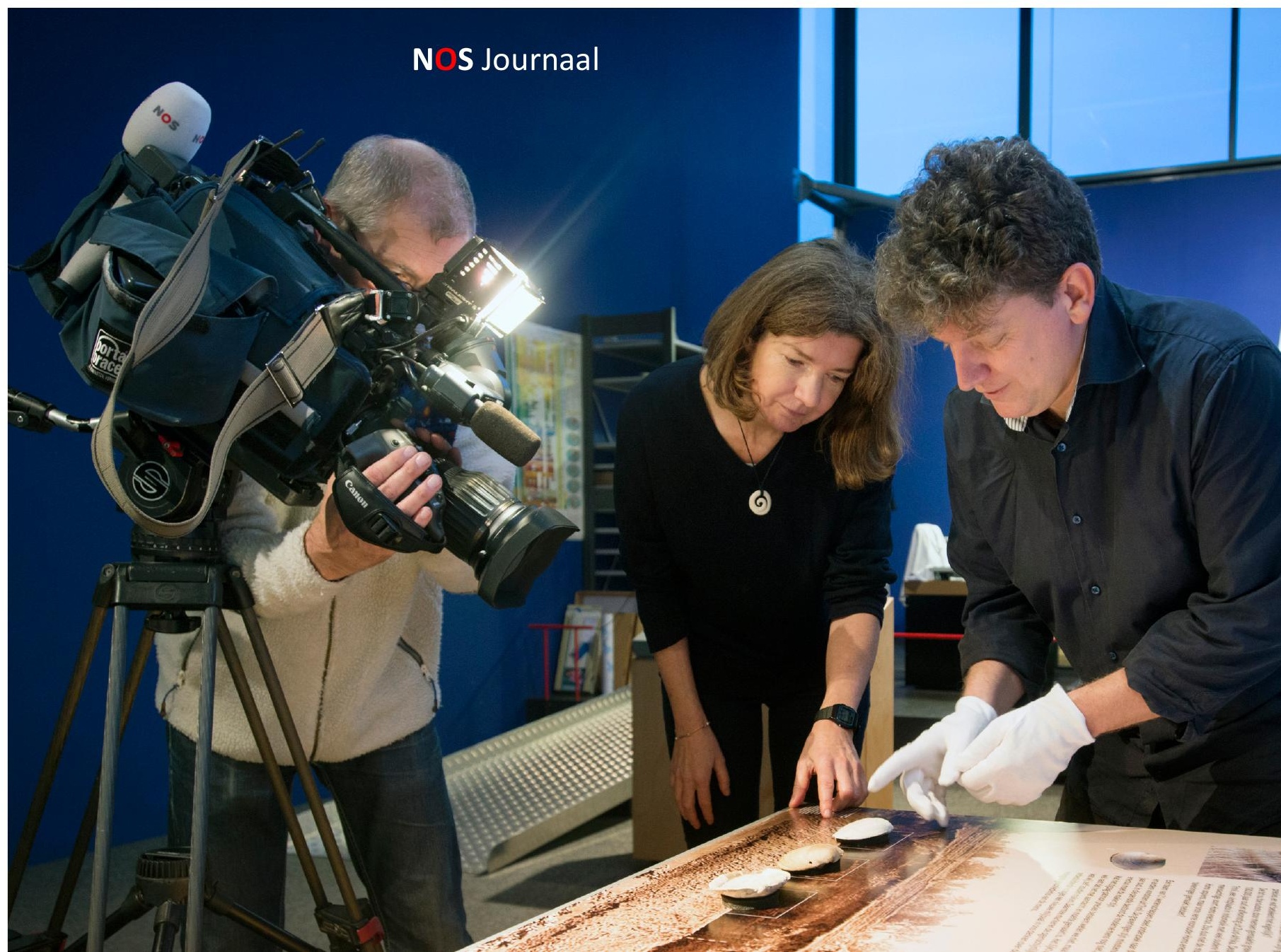




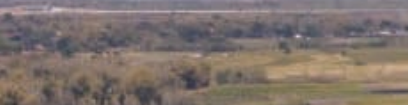

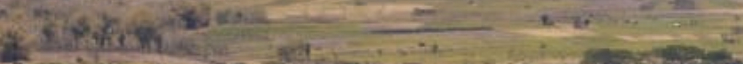

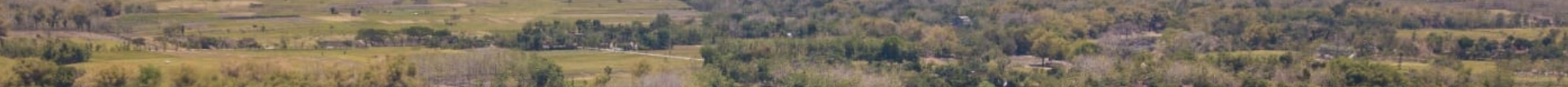

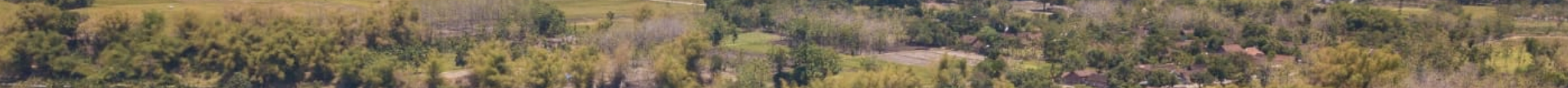

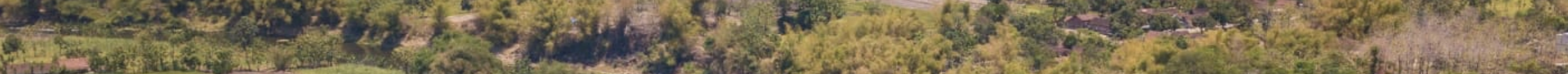

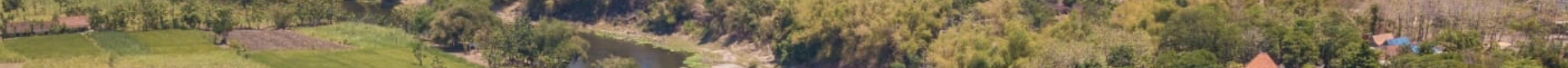

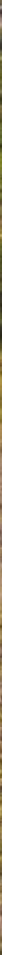

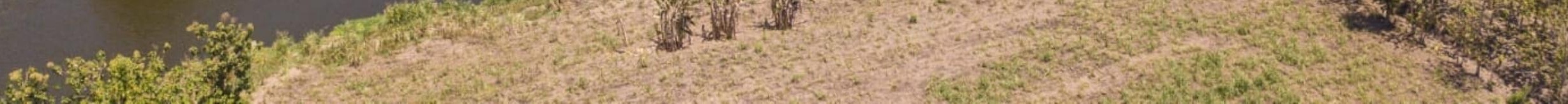


Exaten $x^{2}$

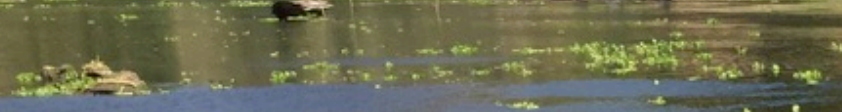
-

\section{Trinil, 2018}




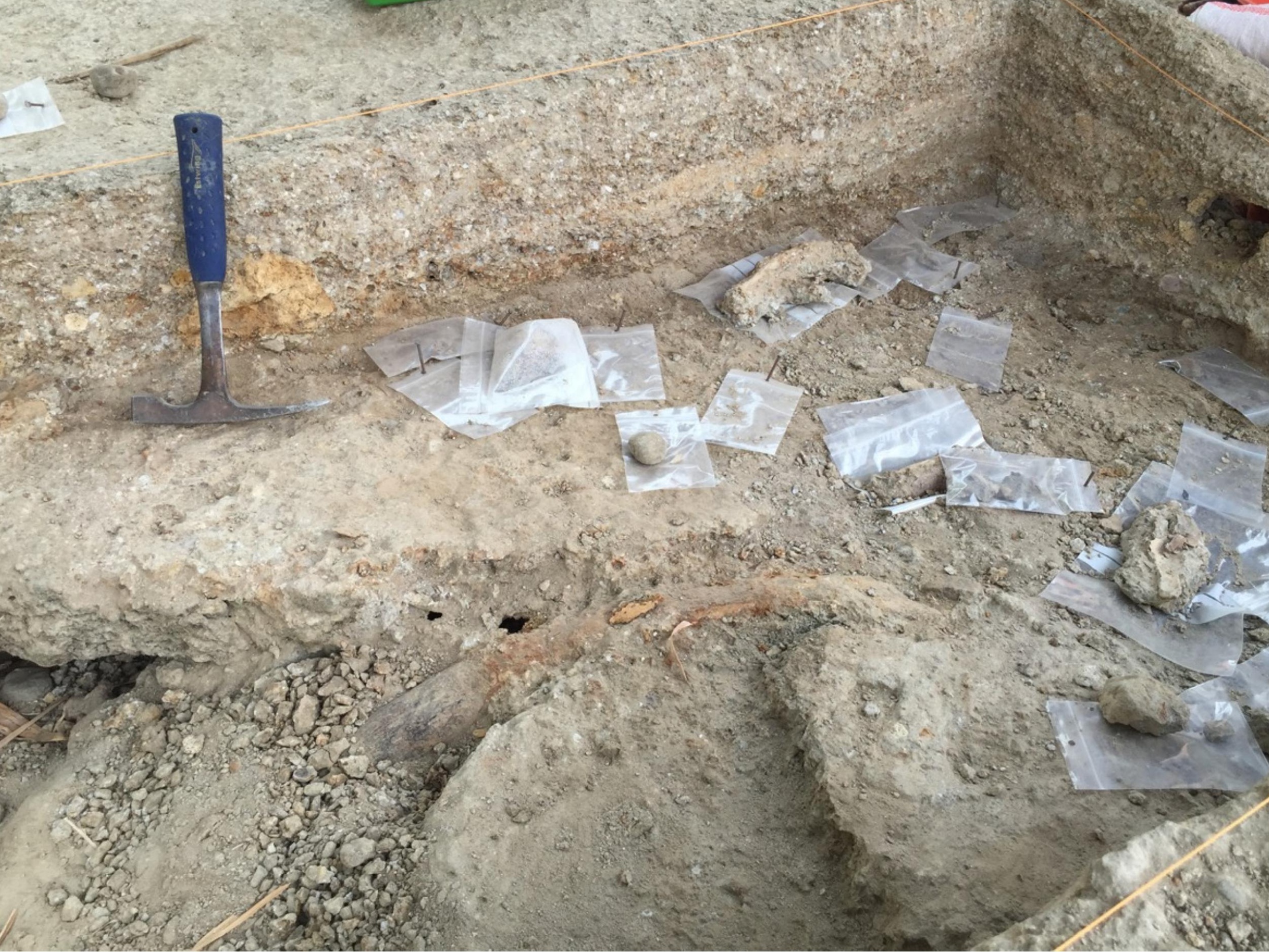



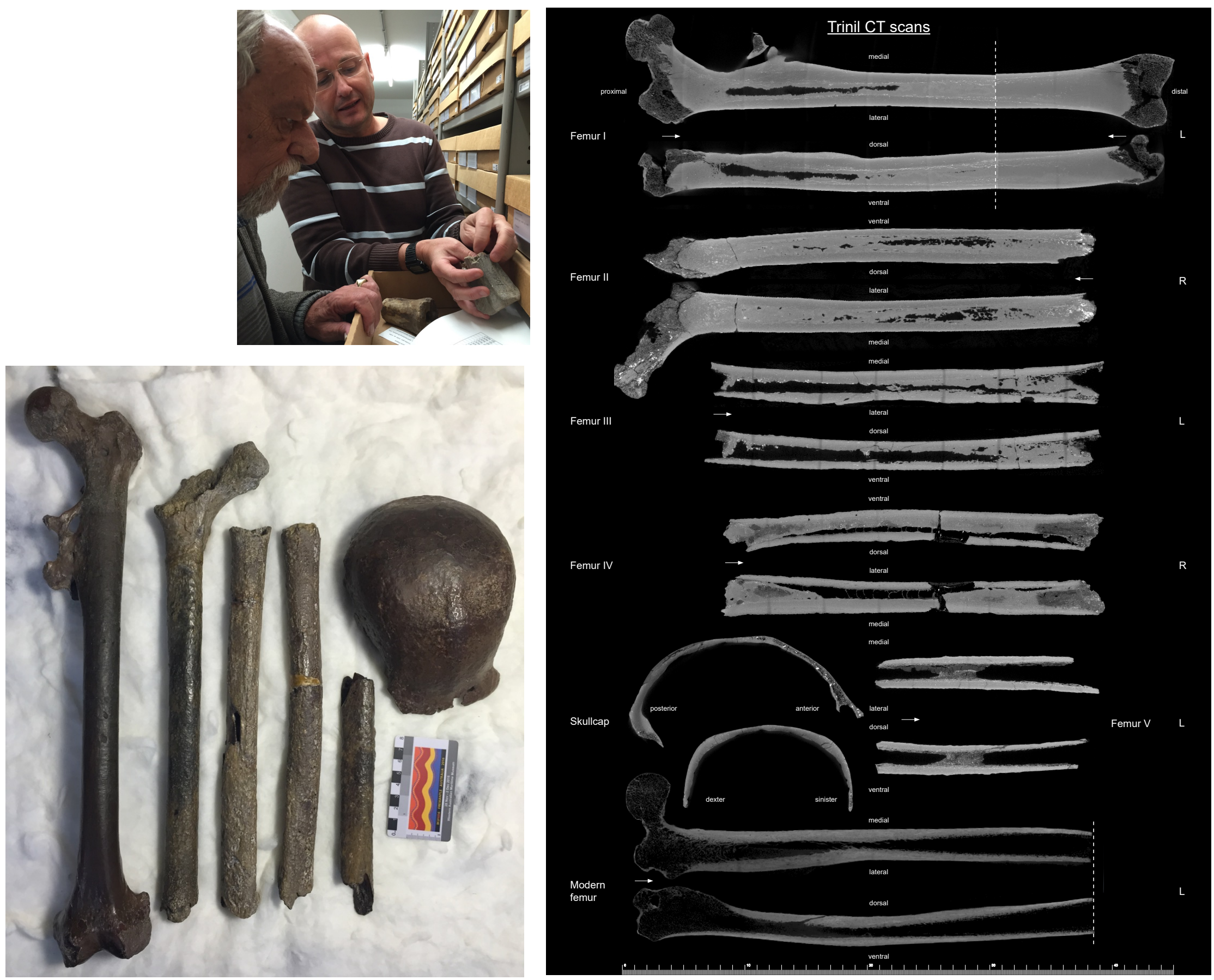


\section{Hominin Paleocology and Evolution}

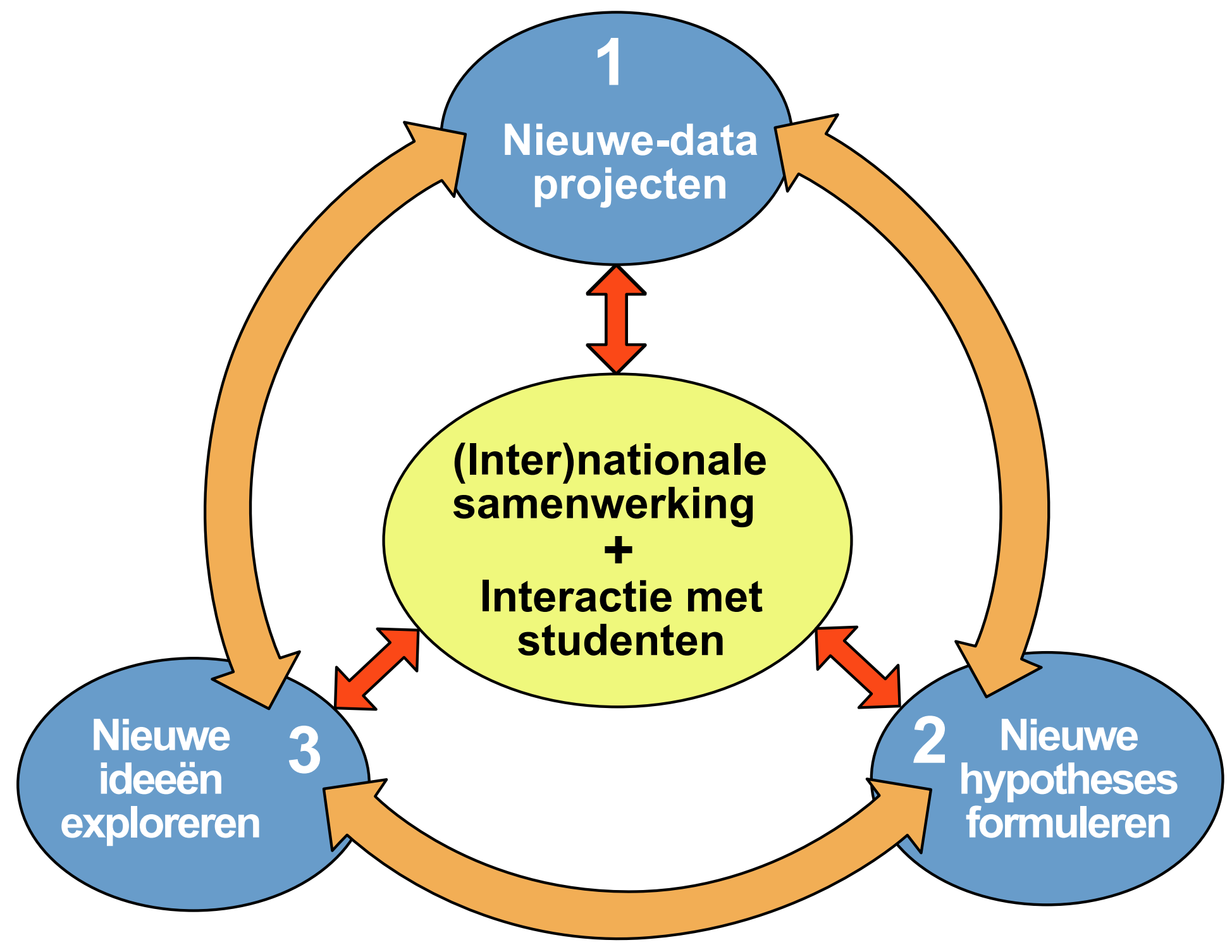




\section{Klimaat plus fossielen per gebied}

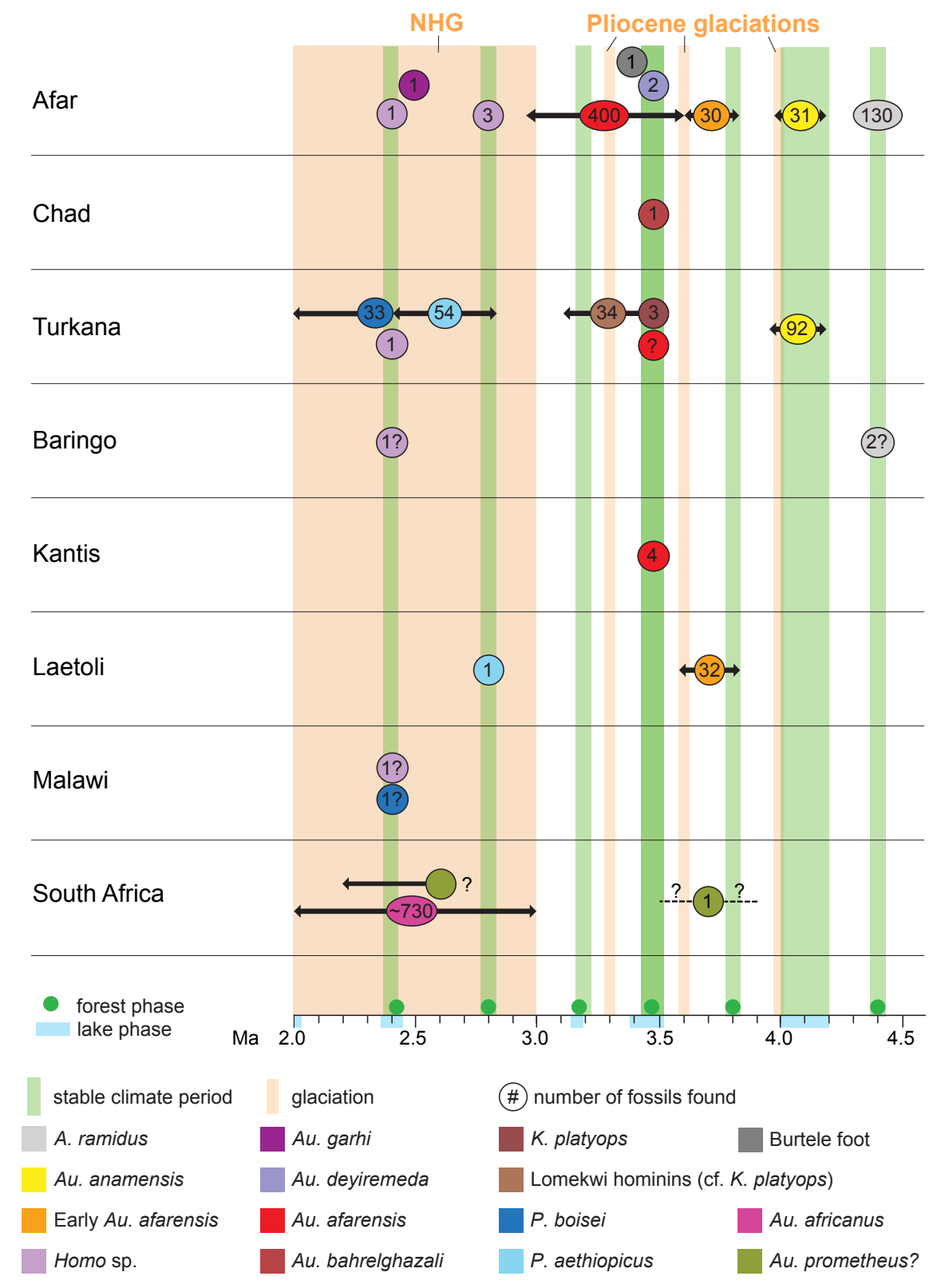

Joordens et al., 2019 


\section{Hypothese: kustbos is oorsprong en refugium}

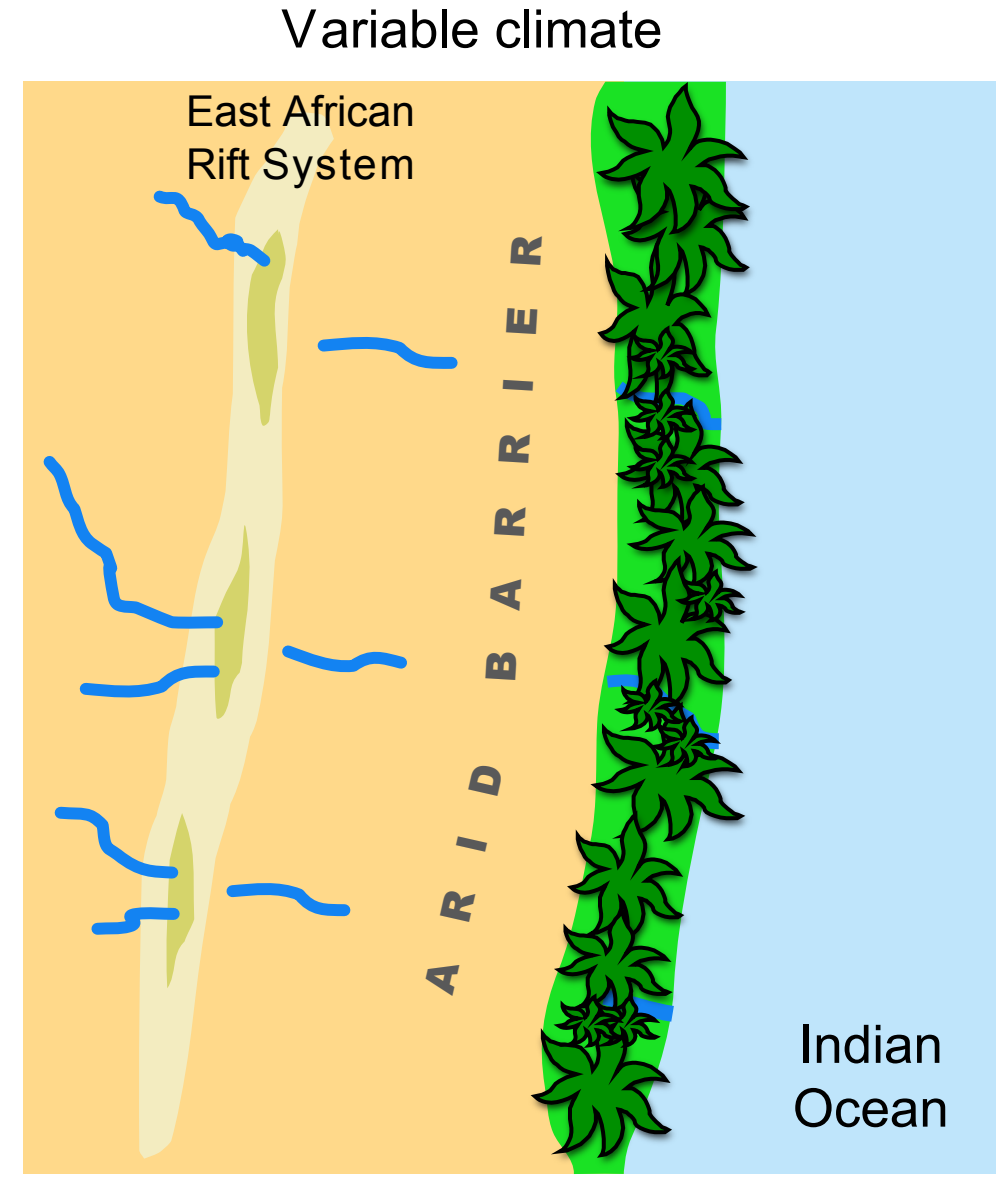

Isolatie en evolutie in kustbos

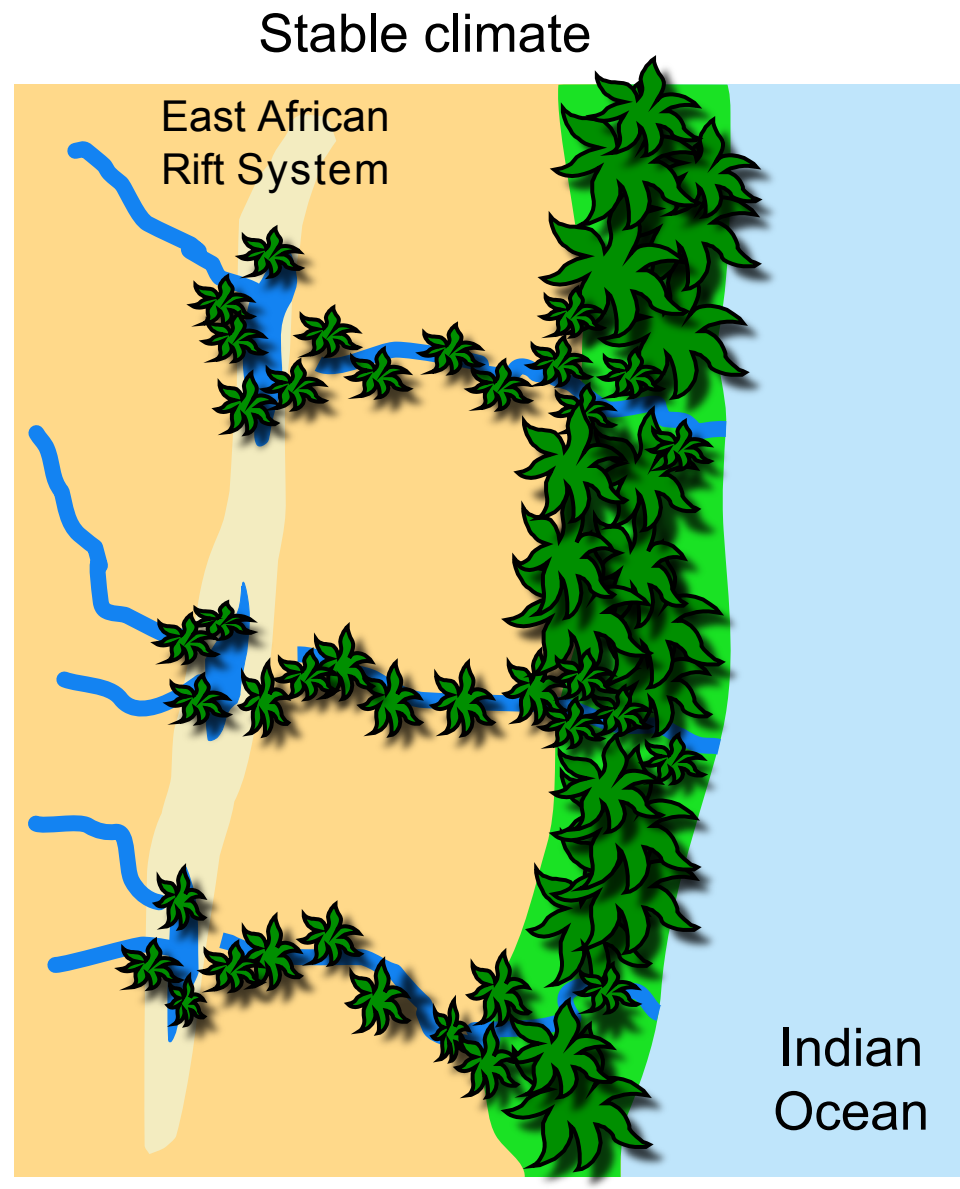

Verspreiding naar het binnenland 


\section{Hominin Paleocology and Evolution}

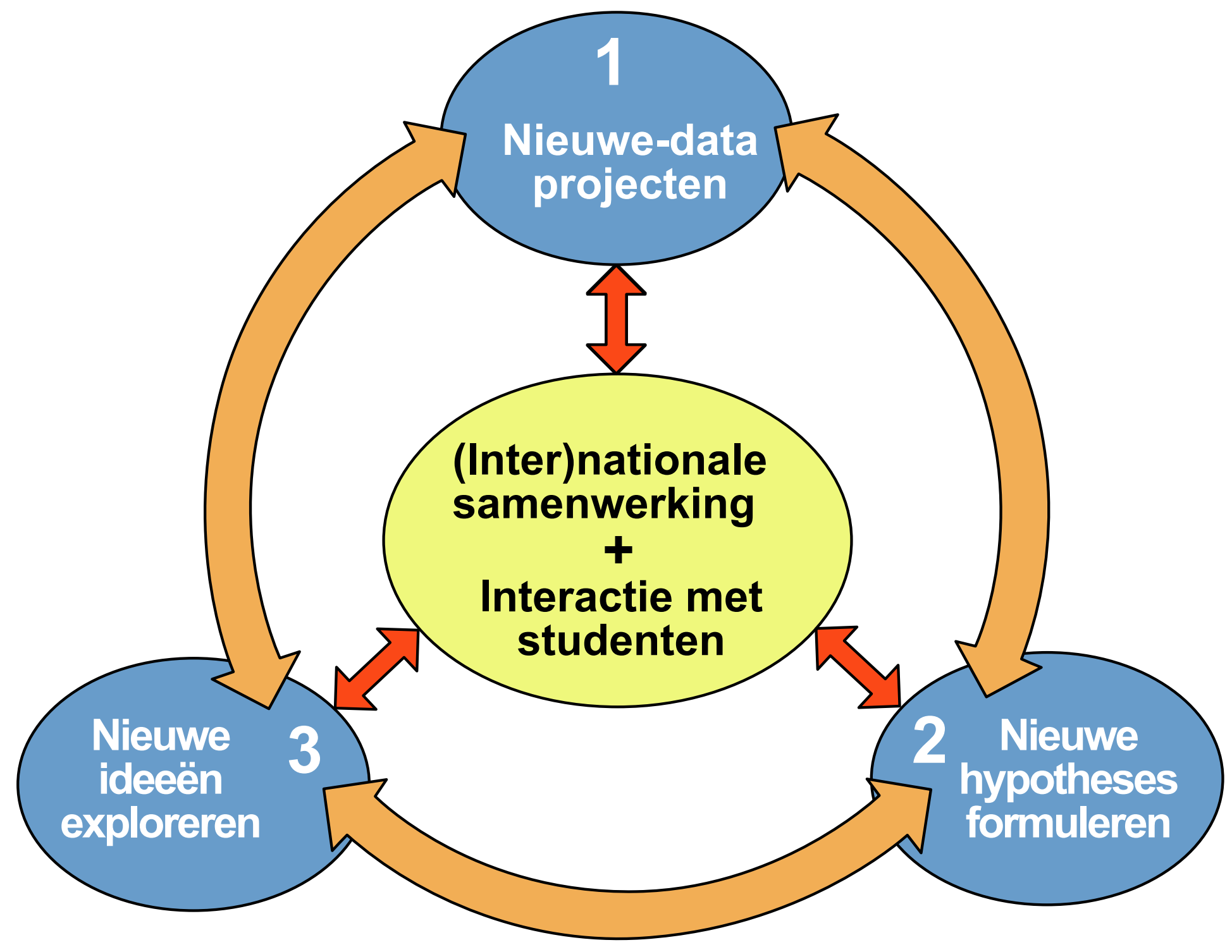




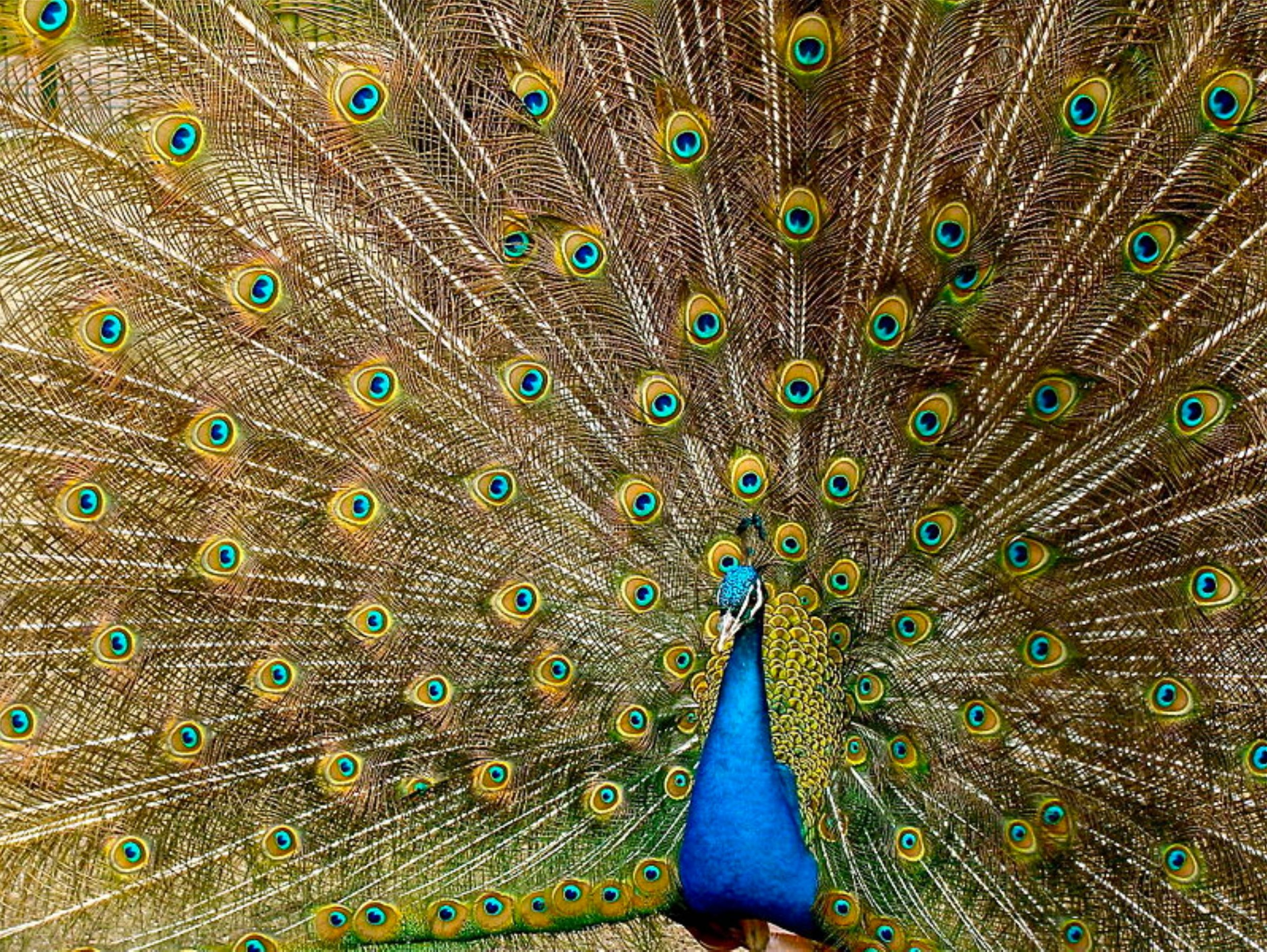


athoniminang

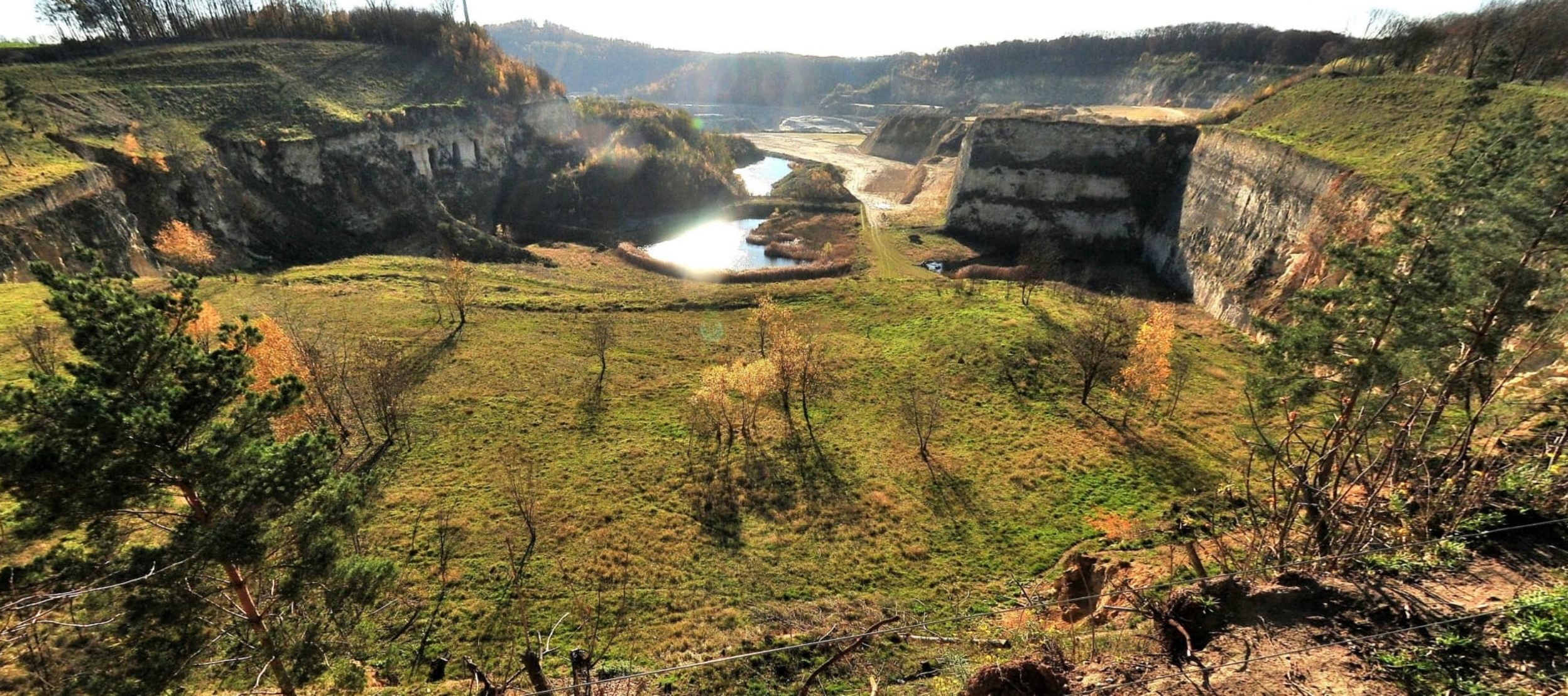


